\title{
THE STUDY OF TIM POLYMER COMPOSITE MATERIALS THERMAL CONDUCTIVITY
}

\author{
Zemlyanskaya A.P.*, Shishkin R.A., Kudyakova V.S., \\ Yuferov Y.V., Zykov F.M. \\ Ural Federal University, Yekaterinburg, Russia \\ *E-mail: zemlyanskaia@mail.ru
}

Recently the main trend in technology is an increase in power and a decrease in overall dimensions, weight in electronic devices. In order to improve the heat transfer between the heating elements and the radiator, thermal interfaces or TIM is applied [12].

One of the most widely used TIMs is a thermal paste, due to their industrial availability. The thermally conductive paste must fill all the airspace that forms, between the central processor and the base of the radiator, and thus ensure the heat exchange between them[3].

Currently, the development of thermal grease, providing good thermal conductivity and acceptable technical and economic parameters.

The aim of the work was to study the effect of the dependence of the thermal conductivity of thermal grease on the physicochemical properties of the filler.

Samples were obtained by mechanical mixing of the PMS-1000 binder and the filler in the alumina mortar. Mixing was carried out until the mechanical properties of the pastes were maintained. The study was carried out on the IT- $\lambda-400$ thermal conductivity meter; the results are presented in table 1 .

Table-1 Data and results of measurements of samples

\begin{tabular}{|l|l|l|l|l|l|l|}
\hline & & $\begin{array}{l}\text { Mass } \\
\text { frac- } \\
\text { tion,\% }\end{array}$ & $\begin{array}{l}\text { Volume } \\
\text { fraction,\% }\end{array}$ & $\begin{array}{l}\text { Average parti- } \\
\text { cle size d3,4 } \\
\text { um }\end{array}$ & $\begin{array}{l}\text { The thermal conduc- } \\
\text { tivity of the } \\
\text { filler, Watt/(m·K) }\end{array}$ & $\begin{array}{l}\text { Thermal con- } \\
\text { fuctivity, } \\
\text { Watt/(m·K) }\end{array}$ \\
\hline 1 & $\mathrm{SiC}$ & 79,56 & 54,08 & 26,90 & 360 & 1,37 \\
\hline 2 & $\mathrm{AlN}$ & 77,34 & 50,41 & 3,20 & 285 & 1,09 \\
\hline 3 & $\mathrm{SiO}_{2}$ & 73,26 & 50,09 & 31,20 & 1,5 & 0,93 \\
\hline 4 & $\mathrm{Graphite}$ & 63,86 & 43,48 & 179,80 & $\| 130,3$ and $\perp 104,7$ & 2,85 \\
\hline 5 & $\mathrm{Al}_{2} \mathrm{O}_{3}$ & 72,94 & 39,85 & 27,40 & 38,5 & 0,73 \\
\hline 6 & $\mathrm{Al}_{2} \mathrm{O}_{3}$ & 60,40 & 27,27 & 62,70 & 38,5 & 0,62 \\
\hline 7 & $\mathrm{Al}_{2} \mathrm{O}_{3}$ & 58,81 & 25,98 & 13,10 & 38,5 & 0,62 \\
\hline 8 & $\mathrm{Cu}$ & 76,25 & 25,86 & 43,50 & 393,00 & 0,97 \\
\hline 9 & $\mathrm{BN}$ & 41,99 & 25,08 & 6,40 & $\| 600$ and $\perp 30$ & 0,85 \\
\hline 10 & $\mathrm{MgO}$ & 52,88 & 23,34 & 2,20 & 59,00 & 0,6 \\
\hline 11 & $\mathrm{Ni}$ & 73,20 & 22,94 & 0,70 & 93,00 & 0,80 \\
\hline 12 & $\mathrm{Al} \mathrm{O}_{3}$ & 52,03 & 21,05 & 53,40 & 38,5 & 0,50 \\
\hline 13 & $\mathrm{Al}$ & 37,02 & 18,58 & 36,00 & 228,00 & 1,20 \\
\hline
\end{tabular}


1. Thermal conductivity significantly increases with a high volume fraction. The highest fraction values are observed for samples with silicon carbide, aluminum nitride, silicon oxide, and graphite fillers.

2. The average particle size of the filler does not significantly affect the value of thermal conductivity.

3. Sample № 13, where the filler is aluminum powder, has a percolation effect, expressed in a sharp increase in thermal conductivity of thermal paste.

4. It is revealed that the most promising materials for further research and development of the optimal composition of thermal paste are silicon carbide, silicon oxide, aluminum nitride, and graphite.

Support by the Ministry of Education and Science of the Russian Federation is gratefully acknowledged: calculation results (chapter 3.1) were obtained under research project \# 3.6064.2017/8.9 and experimental results (chapter 3.2) - under project \# 3.10704.2018/11.12.

1. Chung D.D.L., Applied Thermal Engineering, 21, 1593-1605 (2001).

2. McNamara A.J. et al., International Journal of Thermal Sciences, 62, 2-11 (2012) 2.

3. Due J. et al., Applied Thermal Engineering, 50, 455-463 (2013).

\title{
ПЕРЕРАБОТКА ЖАРОПРОЧНЫХ НИКЕЛЕВЫХ СПЛАВОВ С ПРИМЕНЕНИЕМ СЕРНОКИСЛОГО ЭЛЕКТРОЛИТА
}

\author{
Жилина Е.М., Красиков С.А., Гордеева А.С., Русских А.С. \\ Институт металлургии Уральского отделения Российской Академии наук, \\ Екатеринбург, Россия \\ *E-mail: ezhilina@bk.ru
}

\section{PROCESSING OF HEAT-RESISTANT NICKEL ALLOYS USING SULFURIC ACID ELECTROLITE}

\author{
Zhilina E.M., Krasikov S.A., Gordeeva A.S., Russkih A.S. \\ Institute of Metallurgy of the Ural Branch of the Russian Academy of Sciences, Yekaterin- \\ burg, Russia
}

The paper shows the experimental possibility of obtaining sludge saturated with refractory metals during the electrochemical processing of waste nickel-based superalloys. It is shown that the concentration of sulphate electrolyte has a significant effect on the intensity of the process and contributes to the release of tungsten and tantalum in the resulting slurry

Проблема переработки отходов жаропрочных никелевых сплавов [1] представляет важную исследовательскую задачу, так как связана с извлечением ценных редких элементов в продукты, пригодные для дальнейшего использования. 